УДК 681.121

\title{
FLOW TRANSDUCERS METROLOGICAL PERFORMANCES OPTIMIZATION WITH FLOW BODIES AT FLOW ASYMMETRY CONDITIONS
}

\author{
Ivan Korobko, Anna Pysarets \\ National Technical University of Ukraine «Igor Sikorsky Kyiv Polytechnic Institute», \\ Kyiv, Ukraine \\ E-mail: i.korobko@kpi.ua, anna.v@ukr.net
}

\begin{abstract}
The absence of computer-aided design systems with the choice of flow transducers (FT) for energy resource supply systems determines the relevance criteria developing for evaluating flow transducers effectiveness for liquids and gases. It is advisable to carry out FT optimization with flow bodies by determining rational forms and parameters of hydraulic channel and sensitive element (SE).

The FT accuracy can be estimated depending on its purpose, operating conditions and the nature of the measured medium movement: from a probabilistic accuracy index, by the dynamic error index and the generalized efficiency criterion. The last criterion is based on the criteria for the interaction effectiveness of the measured medium flow with the transducer SE and ensures high sensitivity of the system and measurement accuracy with minimal impact on the parameters of the measured medium.

The article presents the results of the evaluation of the flow asymmetry influence induced by the spatial knee on the operation of transducers with sensitive elements of various spatial forms. The measurement means with a cone-type flowed body directed apex towards the flow are the best under the conditions of minimum error and minimal effect on the measured medium. The obtained results make it possible to clearly determine the instrument installation place in the technological network under conditions of maximum accuracy and minimal impact on the measured medium.
\end{abstract}

Keywords: flow rate transducer; flowed body; flow asymmetry; local hydraulic resistance; optimization.

\section{Introduction}

The task of measuring transducers rational choice arises when creating modern effective systems for measuring liquids and gases flow and quantity. Such systems should provide flow registration with high metrological and operational performances. In addition, recently there is an urgent need to measure the fuel and energy resources and water (FERW) flow and quantity with their flow different dynamics.

This determines the need to develop criteria for transducers comparative evaluation taking into account operating conditions and measurement requirements.

\section{Formulation of the problem}

There are some requirements for modern FERW flow rate transducers (FT) such as the measurement accuracy improving, the achieving measurement results for maximum independence from changes in the measured medium parameters (density, viscosity, pressure, temperature, velocity profile and others), the minimum dependence of metrological performances on operating conditions, increasing reliability, repeatability, and improving dynamic qualities, extending the measurement range to low flow rates, linearity of the transformation characteristic, the improving instrument performance not only at normal conditions but also at extreme conditions (at very low or high temperatures and pressures, vibrations and other), the metrological base sufficiency and other [1-4].
These requirements variety has led to the development of a large number of different measurement methods and instruments based on them. Flow transducers with sensitive elements (SE) in the form of flow bodies in the measured medium flow are widely used to measure the FERW flow and its quantity. These instruments based on the methods of variable pressure drop, vortex, hydrodynamic and tachometric (impeller and turbine).

The need to choose the most appropriate instrument type and design from their wide variety is one of the main problems in organizing a system for FERW flow and quantity effective measurement. The practicability of choosing the FT type is considered at the angle of creating efficient measurement systems. The technological process of FERW supply requires regulation. Process control automation is an integral part of its operation efficiency increasing and reducing irrational FERW losses. Emergencies late identification and elimination causing FERW leaks due to insufficient control of the energy flows values lead to their significant losses.

Methods for determining the rational FT type for particular operating conditions today are not defined, despite the increasing prevalence of methods and instruments for measuring the FERW flow and quantity. Hence their exact mathematical models are missing. Works in this area are mainly devoted directly to the measurement principles, have approximate solutions for the flows interaction with primary transducers, and 
were obtained for cases of particular flows (laminar and turbulent), and do not take into account the hydrodynamic processes that occur in the interaction of fast-flowing and fast-variable flows with flow transducers moving elements [1-7]. Such a rather simplified description of the energy carriers flow rate measurement processes does not reflect the whole variety of phenomena that arise during the FT operation.

The absence of computer-aided design systems with the choice of FT for energy resource supply systems determines the relevance criteria developing for evaluating flow transducers effectiveness for liquids and gases.

It is advisable to carry out FT optimization with flow bodies (hydrodynamic and vortex) by determining rational forms and parameters of hydraulic channel and SE. At the same time main optimization calculations goal is to create an efficient instrument with enhanced metrological performances. This becomes possible by determining the design parameters optimal values; to create a measuring channel and SE with well-streamlined shapes that do not create significant head losses and do not complicate the manufacturing technology; by reducing FT sensitivity to the nonuniformity of the flow velocity profile at the inlet; with a decrease in the transition zone between the laminar and turbulent regimes due to the actual elimination of the fluid motion transient regime.

Hydrodynamic class flow transducers optimization criteria definition

The FT accuracy can be estimated depending on its purpose, operating conditions and the nature of the measured medium movement:

a) from a probabilistic accuracy index (the mathematical expectation and variance of the static error);

b) by dynamic error index (transient process duration, frequency transmission width, ratio of the useful signal to noise, dynamic error magnitude, etc.) [8];

c) by generalized efficiency criterion $[9,10]$ (this criterion is based on the criteria for the interaction effectiveness of the measured medium flow with the transducer SE; this ensures high sensitivity of the system and measurement accuracy with minimal impact on the parameters of the measured medium).

The hydrodynamic type FT output signal is the deformation magnitude or SE deflection, caused by the action of hydrodynamic pressure forces on the measured medium. SE is an elastic design with a flowed body (FB) located in the stream. The hydrodynamic pressure forces value acting on the SE is a function of the measured flow local velocity, the shape and sizes of FB and the measured medium density. Flow local velocity is a velocity in the cross section of the measuring channel with the exception of the FB midship area.

On this basis, optimization task is reduced to determining values of the rational parameters of the hydraulic channel, FB and SE in general. One of the main requirements for the FT is the minimum pressure losses of the measured medium. Therefore, as an optimization criterion, it is advisable to take the criterion of a comprehensive assessment of the instrument influence on the measured medium while ensuring high sensitivity and measurement accuracy [10]

$$
K_{e \phi y}=\frac{16\left(1-\left(B_{1}+B_{2}\right)\left(1-\tau_{\text {YE }} \frac{S_{M}}{S_{0}}\right)^{6} m^{4} S_{0}^{2}\right.}{C_{x}^{2} S_{M}^{2}\left(1-\frac{2 y}{D}\right)^{\frac{6}{m}}\left(2 m^{2}+3 m+1\right)^{2} \rho^{2} u_{M}^{4}} .
$$

Where,

$$
\begin{gathered}
B_{1}=\frac{\sin \beta}{A\left(D_{1}^{2}+C_{1}^{2}\right)}\left\{e^{-D_{1} \tau_{i}}\left(-D_{1} \sin c \tau_{i}-C \cos c \tau_{i}\right)+C\right\} \\
B_{2}=\frac{\cos \beta}{A \cdot\left(D_{1}^{2}+C^{2}\right)}\left\{e^{-D_{1} \tau_{i}}\left(-D_{1} \cos c \tau_{i}-C \cos c \tau_{i}\right)+D_{1}\right\} \\
A=\sqrt{1-\xi^{2}} ; \quad \beta=\operatorname{arctg} \frac{\sqrt{1-\xi^{2}}}{\xi} ; \\
C_{1}=\omega \sqrt{1-\xi^{2}} ; \quad D_{1}=\xi \omega ;
\end{gathered}
$$

$\xi$ is the SE damping factor; $\omega$ is the SE free oscillation frequency; $u_{M}$ is the flow velocity in midship section; $\rho$ is the measured medium density; $C_{x}$ is the SE drag coefficient; $S_{M}$ is the SE midship area; $S_{0}$ is the flow area before SE installation; $D$ is the hydraulic channel diameter; $y$ is the distance between body and flow axes; $\tau_{Y E}$ is the factor that takes into account SE shape influence on the change in the hydraulic channel cross section; $m$ is the exponent factor [8]; $k$ is the flow velocity distribution nonuniformity coefficient over the flow section.

Thus, the task for finding the minimum values of the function (1) is reduced to determining the optimal values of the damping factor $\xi$, the SE free oscillation frequency $\omega$, the SE drag coefficient $C_{x}$, the ratio of the areas of the SE mid-section $S_{M}$ and the flow section before the SE $S_{0}$ at particular measurement conditions.

The mathematical model analysis of the hydrodynamic class FT shows that the damping coefficient and the free oscillation frequency are functions of such design parameters [11]: the SE width in the pinching place $(b)$; SE thickness $(h)$; SE length $(l)$ is the distance from FB center to pinch line; FB diameter (d); the SE material elasticity modulus. The SE drag coefficient $C_{x}$ and the ratio of the areas of the $\mathrm{SE}$ midship section $S_{\mu}$ and the flow section before the SE $S_{0}$ depend on the size and shape of the FB and SE in general (fig. 1). 


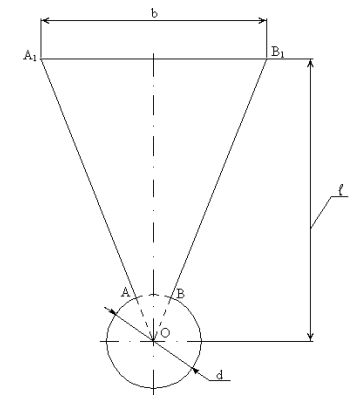

Fig. 1. Sensitive element

Considering the decisive influence of these design parameters on the hydrodynamic type transducer metrological performances, it is appropriate to select them as design parameters.

Interaction estimation of a non-uniform stream with various spatial configuration $\mathrm{SE}$

Interaction estimation of the non-uniform stream with various spatial configurations SE and its influence on the main instrument performances were carried out for flow transducers. The SE of these transducers have different streamlined surfaces of different Gaussian curvature: zero (disk) (Fig. 2), positive (cone) and negative (hollow hemisphere).

For the mentioned transducers numerical modeling was carried out for such conditions (Table 1): nominal diameter $D N=32 \cdot 10^{-3} \mathrm{~m}$; measured medium - water; starting flow rate $2,22 \cdot 10^{-6} \mathrm{~m}^{3} / \mathrm{s}$; minimum flow rate $1,38 \cdot 10^{-3} \mathrm{~m}^{3} / \mathrm{s}$; nominal flow rate $4,166 \cdot 10^{-3} \mathrm{~m}^{3} / \mathrm{s}$; maximum flow rate $6,944 \cdot 10^{-3} \mathrm{~m}^{3} / \mathrm{s}$; maximum pressure of medium 1,6 Pa; measured medium temperature $293^{\circ} \mathrm{K}$; measuring length $131,76 \cdot 10^{-3} \mathrm{~m}$; SE length $73,16 \cdot 10^{-3} \mathrm{~m}$; the SE width in the pinching place $25,92 \cdot 10^{-3} \mathrm{~m}$; SE thickness $1 \cdot 10^{-3} \mathrm{~m}$; FB diameter $8,07 \cdot 10^{-3} \mathrm{~m}$.

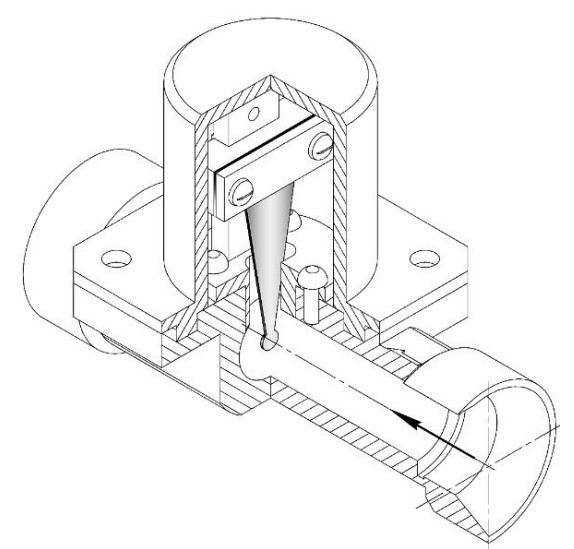

Fig. 2. The transducer with a sensitive element, its FB is made as flat disk

Table 1. Instruments under study

\begin{tabular}{|l|c|c|c|}
\hline \multirow{2}{*}{\multicolumn{2}{|c|}{ Parameter }} & \multicolumn{3}{c|}{ Transducer } \\
\cline { 2 - 4 } & № 1 & $№ ~ 3$ \\
\hline Flowed body form & disk & cone & hollow hemisphere \\
\hline Flowed body (FB) spatial orientation & basis on stream & top to stream & concave part on stream \\
\hline
\end{tabular}

Measurement errors are determined depending on the angle of instrument spatial orientation on the technological network and the distance from the local hydraulic resistance.

The transducers investigations made in the presence at the technological network of various configurations hydraulic resistances.

The FT accuracy can be estimated by determining the non-conformity degree of the SE deformation, taking into account the cross section invariance. This deformation is caused by the action of the Grego model symmetric profile [12] and of the velocity head in the studied cross-section. The Grego symmetrical profile describes a developed turbulent flow in a pipeline with a circular cross section.

When assessing the flow asymmetry effect on the transducers accuracy, the velocity diagram was reconstructed in the input cross-section of the hydraulic resistance model geometry. This plot corresponds to the distribution that occurs when a stream passes a certain resistance at a particular distance from the initial cross-section.

Studies of the flow nonuniformities effect on the transducer operation were carried out by evaluating the measurement errors magnitude, the effect on the measured medium, and the efficiency coefficient values. The effect on the measured medium is characterized by pressure losses on the instrument. Efficiency coefficient comprehensively reflects measurement accuracy and effect on flow (1).

The article presents the evaluation results of the flow asymmetry influence induced by the spatial knee on the operation of transducers with sensitive elements of various shapes.

When simulating the local resistances influence on the fluid flow hydrodynamic characteristics in each cross section of the hydraulic channel (fig. 3), the values of the velocity vectors projections along four axes (diametral chords) are obtained I-I $(0-0)$; II-II $(\pi / 4$ $\pi / 4)$; III-III $(\pi / 2-\pi / 2)$; IV-IV $(3 \pi / 4-3 \pi / 4)$ (fig. 4 ). 


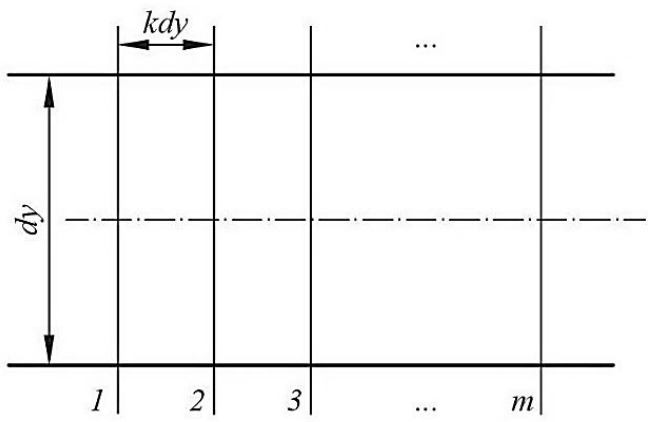

Fig. 3. The scheme of scanning the velocity vectors along the hydraulic channel: dy - hydraulic channel diameter; $\mathrm{k}$ - cross section number; $\mathrm{m}$ - number of cross sections

Based on the results of assessments of the flows nonuniformity degree, cross sections at distances of 9 , $14,19,24,30$ and 50 nominal diameters from the input section were selected for the studies. The corresponding velocity profiles were fed to the models input.

Evaluation of the instrument operation qualitative and quantitative features, caused by the flow asymmetry, was carried out by numerical simulation, for each of the specified sections, for four cases of transducer spatial orientation relative to its vertical axis (fig. 4). In this case, the rotation angle was counted clockwise with a resolution of $\pi / 4$ radians. At the same time, a complex criterion of efficiency (fig. 5), measurement error (fig. 6) and pressure loss (fig. 7) were determined.

The results analysis shows the places of the transducer most appropriate placement in the technological network as relating to hydraulic resistance are clearly defined. A sharp increase in the efficiency coefficient is observed with a decrease in the error magnitude after the 27 th cross-section.

The change in the instrument spatial orientation relative to the vertical axis makes it possible to achieve high measurement accuracy in cross sections along the process line with minimal impact on the flow.

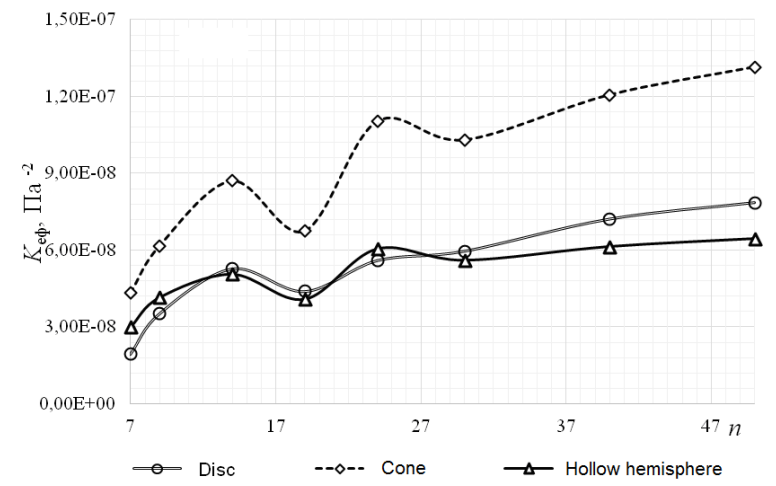

Fig. 5. The flow transducer efficiency coefficient at the instrument orientation angle $\theta=0$ radians

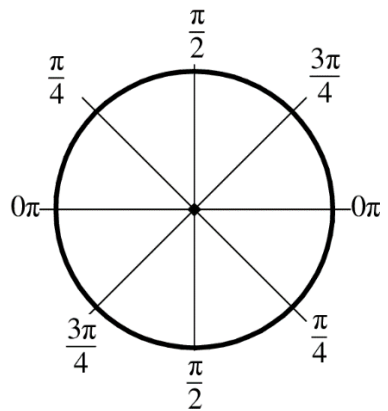

Fig. 4. Diagram of velocity vectors projections in cross section

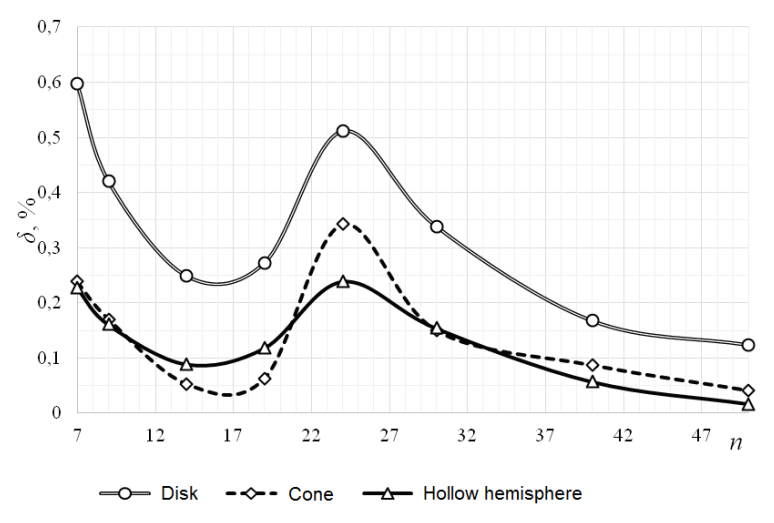

Fig. 6. The flow transducer error at the instrument orientation angle $\theta=0$ radians

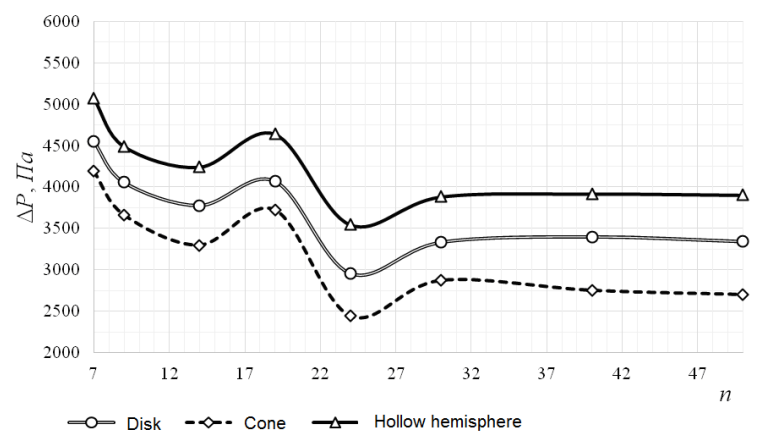

Fig. 7. The flow transducer pressure losses at the instrument orientation angle $\theta=0$ radians

The instruments have the smallest error when oriented at an angle of $\theta=3 \pi / 2$ radians relative to the vertical axis. At such transducer spatial orientation, the measurement errors for structures with flowed cone-type bodies and a bowl after the 25th cross-section do not exceed $0.1 \%$. In this case, the first measuring instrument has a smaller effect on the flow hydrodynamic characteristics.

\section{Conclusions}

The researches of hydrodynamic flow meters with sensitive elements of various spatial forms made 
it possible to draw the following conclusions. The measurement means with a cone-type flowed body directed apex towards the flow are the best at the conditions of minimum error and minimal effect on the measured medium.

Other classes of instruments are characterized by smaller values of the efficiency coefficient and measurements accuracy with large pressure losses. At the same time, an analysis of the study results of the generalized efficiency criterion dependence of a hydrodynamic type transducer on the degree of the cross section filling and the flowed body shape showed that the most optimal are sensitive elements with flowed bodies in the form of a hollow hemisphere and disk.

The obtained results make it possible to clearly determine the instrument installation place in the technological network at conditions of maximum accuracy and minimal impact on the measured medium. This allows to effectively use the transducers in the technological networks, taking into account the measurement organization specific conditions. There is no necessary to make straight pipeline sections before and after the instruments.

The formulated optimality criterion allows to evaluate the measuring transducers operation for fluid flow different modes in the measured flow rates wide range.

Further work will be aimed at evaluation the influence of local hydraulic resistances of various spatial orientations on the measuring instruments use effectiveness.

\section{References}

[1] П. П. Кремлевский, Расходомеры и счетчики количества веществ: Справочник: Кн. 1. - 5-е изд. перераб. и доп. Санкт-Петербург, Россия: Политехника, 2002.

[2] П. П. Кремлевский, Расходомеры и счетчики количества веществ: Справочник: Кн. 2. - 5-е изд., перераб. и доп. Санкт-Петербург, Россия: Политехника, 2004.
[3] Е. А. Шорников, Расходомеры и счетчики газа, узль учета: справочник. СанктПетербург, Россия: Политехника, 2003.

[4] К. И. Хансуваров, В. Г.Цейтлін, Техника измерения давления, расхода, количества и уровня жидкости, газа и пара: Учебное пособие для техникумов. Москва, СССР: Изд-во стандартов, 1990.

[5] А. А. Тупиченков, О. А. Абдурашитов, Э. С. Мануков, Счетчики жидкости. Москва, СССР: Изд-во стандартов, 1980.

[6] А. Ш. Киясбейли, Л. М. Лифшиц, Первичные преобразователи систем измерения расхода $u$ количества жидкостей. Москва, СССР: Энергия, 1980.

[7] Б. В. Бирюков, М. А. Данилов, С. С. Кивилис, Испьтания расходомеров. Москва, СССР: Изд-во стандартов, 1987.

[8] А. Д. Альтшуль, Гидравлические потери на трение в трубопроводах. Москва - Ленинград, СССР: Госэнергоиздат, 1963.

[9] I. В. Коробко, “Оцінка ефективності вимірювальних перетворювачів витрати рідин і газів", Вісн. НТУУ "КПI". Серія приладобудування, Вип. 44, с. 111-117, 2012.

[10] I. В. Коробко, “Оптимізація вимірювальних перетворювачів витрати рідини гідродинамічного типу", Вісник НТУУ "КПІ”. Серія приладобудування, Вип. 46, с. 91-96, 2013.

[11]I. В. Коробко, “Визначення коливальної маси чутливого елементу вимірювального перетворювача витрат гідродинамічного типу”, Пращзі Тавр. держ. агротехнік. академ. Вип.4, Том 22, c.87-93, 2003.

[12] G. Wendt, T. Jahn, A. Hein, U. Jakubczyk, "Untersuchung und Entwicklung strömungsprofilunempfindlicher Wasser- und Wärmezähler und deren mechanischer Schnittstellen", PTB-Bericht PTB-MA-90 Zugl., Sept., p. 132, 2012.

\section{УДК 681.121}

\section{I. В. Коробко, А. В. Писарець}

Національний технічний університет Украйни «Київський політехнічний інститут імені Ігоря Сікорського», Київ, Украӥна ОПТИМІЗАЦІЯ МЕТРОЛОГІЧНИХ ХАРАКТЕРИСТИК ПЕРЕТВОРЮВАЧІВ ВИТРАТИ 3 ТІЛАМИ ОБТІКАННЯ ЗА УМОВ ВПЛИВУ АСИМЕТРІЇ ПОТОКУ

Однією з головних проблем при організації системи ефективного вимірювання витрати та кількості паливноенергетичних ресурсів та води (ПЕРВ) є необхідність вибору найбільш доцільних типу і конструкції приладу 3 їх широкого різноманіття. Не дивлячись на все більше розширення застосування методів і приладів вимірювання витрати та кількості ПЕРВ, методики вибору раціонального типу ВПВ для певних умов застосування, на сьогодні не визначені.

Оптимізацію вимірювальних перетворювачів витрати (ВПВ) із тілами обтікання доцільно здійснювати шляхом визначення раціональних форм і параметрів вимірювальних ділянок та чутливих елементів (ЧЕ).

Залежно від умов експлуатаційного використання точність ВПВ можна оцінювати за: ймовірнісним показником точності, показником динамічної похибки та узагальненим критерієм ефективності. 
Тестування перетворювачів здійснювалися за наявності в технологічній мережі місцевих гідравлічних опорів різної конфігурації. Дослідження впливу неоднорідностей потоку на роботу перетворювача проводилися за оцінюванням величини похибок вимірювання, впливу на вимірюване середовище, що характеризується втратою тиску на приладі, та значень коефіцієнту ефективності, який комплексно відображає точність вимірювання і дію на потік.

У статті наведено результати оцінювання впливу асиметрії потоку, індукованої просторовим коліном на роботу перетворювачів із різною формою ЧЕ.

Оцінювання якісних і кількісних особливостей роботи приладу, викликаних асиметричністю потоку, проведено чисельним моделюванням, для перерізів, розташованих на відстанях 9, 14, 19, 24, 30 та 50_номінальних діаметрів від вхідного перерізу, за чотирьох випадків просторової орієнтації перетворювача відносно його вертикальної вісі, при відліку кута повороту за годинниковою стрілкою із дискретністю $\pi / 4$ рад.

Дослідження гідродинамічних витратомірів з чутливими елементами різних просторових форм довели, що найкращими, за умов мінімальної похибки і впливу на вимірюване середовище, $є$ засоби вимірювання 3 тілом обтікання у формі конуса, направленого вершиною назустріч потоку.

Отримані результати дають чітку картину місць локального розміщення приладів на технологічній мережі відносно гідравлічного опору за умов максимальної точності і мінімальної дії на вимірюване середовище.

Ключові слова: перетворювач витрати; тіло обтікання; асиметрія потоку; місцеві гідравлічні опори; оптимізація.

\section{И. В. Коробко, А. В. Писарец}

Национальный технический университет Украины «Киевский политехнический институт имени Игоря Сикорского», Киев, Украина

\section{ОПТИМИЗАЦИЯ МЕТРОЛОГИЧЕСКИХ ХАРАКТЕРИСТИК ПРЕОБРАЗОВАТЕЛЕЙ} РАСХОДА С ТЕЛАМИ ОБТЕКАНИЯ В УСЛОВИЯХ ВЛИЯНИЯ АСИММЕТРИИ ПОТОКА

Несмотря на широкое распространение методов и приборов для измерения расхода и количества топливноэнергетических ресурсов и воды, методики определения рационального класса измерительного преобразователя расхода (ИПР) для определенных условий эксплуатации на сегодня не определены.

Оптимизацию ИПР с телами обтекания целесообразно осуществлять путем определения рациональных форм и параметров измерительных участков и чувствительного (ЧЭ).

В зависимости от назначения ИПР, условий работы и характера движения измеряемого потока, его точность можно оценить по вероятностному показателю точности; показателю динамической погрешности; обобщенному критерию эффективности, который основывается на критериях эффективности взаимодействия потока измеряемой среды с ЧЭ преобразователя, что обеспечивает высокие чувствительность системы и точность измерений при минимальных потерях давления.

Исследования преобразователей осуществлялись при наличии в технологической сети гидравлических сопротивлений различной конфигурации. В статье приведены результаты оценки влияния асимметрии потока, индуцированной пространственным коленом, на работу преобразователей с ЧЭ различной формы.

Исследования гидродинамических расходомеров с чувствительными элементами различных пространственных форм свидетельствуют о том, что средства измерения с телом обтекания в форме конуса, направленного вершиной навстречу потоку, являются наилучшими при условиях минимальной погрешности и минимального влияния на измеряемую среду.

Полученные результаты позволяют четко определить место установки прибора в технологической сети относительно местного гидравлического сопротивления при условиях максимальной точности и минимального влияния на измеряемый поток.

Ключевые слова: преобразователь расхода; тело обтекания; асимметрия потока; местные гидравлические сопротивления; оптимизация.

Надійшла до редакиії 06 травня 2019 року

Рецензовано 15 травня 2019 року 